\section{General journal policies and guidelines for publication in Ciencias Marinas}

Compilation by:

Melba De Jesus

Journal managing editor

\section{INTRODUCTION}

The following document is an enhanced, extended version of our previously known Instructions for Authors. It was elaborated to give you more detailed information about our journal foundations and our basic requirements for publication in Ciencias Marinas. This extended version first addresses general questions about our journal so you know where you are publishing. It then describes our journal policies, and it finally elaborates on submission and manuscript preparation guidelines. Modifications to this document will undoubtedly be made in the future as we undertake arising issues, but for now we hope it serves your needs with regard to Ciencias Marinas, or CM as we will refer to it from now on except in headings.

\section{About Ciencias Marinas}

\section{What is Ciencias Marinas}

A bilingual open-access publication, $\mathrm{CM}$ is an international peer-reviewed journal that contains original research findings in all areas of marine science. It is published quarterly by the Autonomous University of Baja California, Mexico, and all its contents are publicly available on our journal website. Though a limited number of copies are still printed, the journal is mainly distributed in its electronic format.

CM was launched in 1973 as an academic project aimed to entice local researchers to publicly disclose their findings by adopting the culture of peer-review publishing, and the first issue was published in June 1974. Soon, the journal included papers from researchers in the United States and, eventually, other parts of the world. Because of the diversity in authorship, CM issues were initially published in either Spanish or English, and occasionally in both languages. It was not until 1984 when CM included both language versions of all its contents, and it then became the fully bilingual journal it still is today. At CM we believe our inclusive format allows us not only to address a wider range of submissions from international authors but also to make published findings available to a wider international audience.

So whether you are looking for information on the redfish in Icelandic waters or the physical and bio-logical properties of the Gulf of California, feel free to peruse CM

\section{Políticas editoriales generales y directrices para publicar en Ciencias Marinas}

\author{
Compilación por: \\ Melba De Jesus \\ Coordinadora editorial
}

\section{INTRODUCCIÓN}

El siguiente documento es una versión extendida y mejorada de lo que previamente llamábamos Instrucciones para los Autores. Fue elaborado para ofrecerte información más detallada sobre los fundamentos para nuestra revista y sobre los requerimientos básicos para publicar en Ciencias Marinas. Esta versión extendida primero aborda algunas preguntas generales sobre nuestra revista para que tú sepas dónde estás publicando. Posteriormente, describe nuestras políticas editoriales, y finalmente detalla sobre las directrices para someter y preparar un manuscrito. Seguramente se harán modificaciones a este documento en el futuro conforme abordemos nuevas situaciones, pero mientras esperamos que pueda ser un buen material de apoyo para tus necesidades relacionadas con Ciencias Marinas, o CM, como la llamaremos de ahora en adelante excepto en los encabezados.

\section{ACERCa de Ciencias Marinas}

\section{Qué es Ciencias Marinas}

Una publicación bilingüe de acceso abierto, $\mathrm{CM}$ es una revista arbitrada internacional que contiene hallazgos originales de investigación en todas las áreas de las ciencias del mar. Es publicada trimestralmente por la Universidad Autónoma de Baja California, México, y su contenido está disponible al público a través nuestra página web. Aunque aún se imprime un número limitado de copias, la revista es distribuida principalmente en su formato electrónico.

La revista fue creada en 1973 como un proyecto académico con la intención de cautivar a los investigadores locales a adoptar la cultura de la publicación arbitrada y revelar sus hallazgos. La revista pronto incluyó artículos de investigadores provenientes de Estados Unidos y, eventualmente, de otras partes del mundo. Debido a la diversidad en los autores, los primeros fascículos de CM se publicaban ya sea en español o en inglés, y sólo ocasionalmente en ambos idiomas. No fue hasta 1984 que CM incluyó ambas versiones de todos sus artículos, y fue entonces que se convirtió en la revista bilingüe que actualmente es. En CM creemos que nuestro formato inclusivo nos permite no solo evaluar envíos de una gama amplia de autores internacionales, sino también llevar los hallazgos publicados a una audiencia internacional más amplia. 
contents. You may find them to provide source material for your research.

\section{Who reads Ciencias Marinas}

$\mathrm{CM}$ is a multidisciplinary journal about research in the different areas of marine science and is thus consulted by a broad international audience. CM readership extends to environmental consultants and federal and private agents, but it primarily encompasses members from the science community invested in the field of marine science.

\section{Where to find Ciencias Marinas (indexing)}

$\mathrm{CM}$ is an open-access journal. You may fully access journal contents directly through the journal website (www. cienciasmarinas.com.mx) or via the two following sources: Scientific Electronic Library Online (SciELO) and Red de Revistas Científicas de América Latina y el Caribe, España y Portugal (Redalyc). Please note that the latter two sources may not have our latest issues available.

$\mathrm{CM}$ is also indexed or abstracted in:

- Science Citation Index

- Science Citation Index Expanded

- SciELO Citation Index

- Scopus

- Directory of Open Access Journals (DOAJ)

- Current Contents

- Academic Search Complete

- Aquatic Sciences and Fisheries Abstracts (ASFA)

- Biological Abstracts

- Environmental Abstracts

- Marine Affairs Bibliography

- Zoological Record

- Sistema de Clasificación de Revistas Mexicanas de Ciencia y Tecnología del CONACYT

- Scientific Electronic Library Online (SciELO México)

- Red de Revistas Científicas de América Latina, el Caribe, España y Portugal (Redalyc)

- Latindex

- COMPLUDOC

- Periódica (Índice de Revistas Latinoamericanas en Ciencias)

\section{Who makes Ciencias Marinas}

$\mathrm{CM}$ is a compilation of the collective effort of

- Authors: Researchers from all over the world, credited as main contributors as they provide the main contents.

- Editor-in-chief: A renowned researcher responsible for selecting the journal contents and pursuing the journal goals.

- Associate editors: Active researchers from different parts of the world performing studies in different fields of
Así que, ya sea que estés buscando información sobre la gallineta nórdica en aguas islándicas o sobre las propiedades físicas y biológicas del golfo de California, tómate la libertad de examinar el contenido de CM. Quizás en él encuentres información fundamental para tu investigación.

\section{Quién lee Ciencias Marinas}

$\mathrm{CM}$ es una revista multidisciplinaria sobre investigación en las diferentes áreas de las ciencias del mar y, por tanto, es consultada por una amplia audiencia internacional. El público lector de CM incluye desde consultantes ambientales hasta agentes federales y privados, pero principalmente comprende miembros de la comunidad científica involucrados en el campo de las ciencias del mar.

\section{Dónde encontrar a Ciencias Marinas (indización)}

$\mathrm{CM}$ es una revista de libre acceso. Puedes acceder al contenido completo de nuestra revista directamente a través de nuestra página web (www.cienciasmarinas. com.mx) o a través de las siguientes fuentes electrónicas: Scientific Electronic Library Online (SciELO) y Red de Revistas Científicas de América Latina y el Caribe, España y Portugal (Redalyc). Por favor toma en cuenta que nuestros números más recientes pueden no estar disponibles en estas últimas dos fuentes.

$\mathrm{CM}$ también se encuentra indizada o resumida en:

- Science Citation Index

- Science Citation Index Expanded

- SciELO Citation Index

- Scopus

- Directory of Open Access Journals (DOAJ)

- Current Contents

- Academic Search Complete

- Aquatic Sciences and Fisheries Abstracts (ASFA)

- Biological Abstracts

- Environmental Abstracts

- Marine Affairs Bibliography

- Zoological Record

- Sistema de Clasificación de Revistas Mexicanas de Ciencia y Tecnología del CONACYT

- Scientific Electronic Library Online (SciELO México)

- Red de Revistas Científicas de América Latina, el Caribe, España y Portugal (Redalyc)

- Latindex

- COMPLUDOC

- Periódica (Índice de Revistas Latinoamericanas en Ciencias)

\section{Quiénes componen Ciencias Marinas}

CM es una compilación del esfuerzo colectivo de

- Autores: Investigadores de todo el mundo, acreditados como principales contribuyentes ya que ellos proporcionan el contenido principal. 
marine science; they ensure content quality and manage the review process.

- Reviewers: Active researchers from different parts of the world, credited as essential contributors because they help guarantee the quality of the science being described.

- In-house editors: Full-time editors committed to ensure publication quality by safeguarding language readability, accuracy, and consistency; they also polish the style, format, and looks of the journal.

\section{What to publish in Ciencias Marinas}

Publications in $\mathrm{CM}$ are primarily reports and notes of original research in all areas in the field of marine science, including but not limited to marine biochemistry, physical oceanography, fishery biology, marine ecology, conservation, genetics, and aquaculture. CM also features review articles and comments. Four categories of contributions are accepted for publication:

\section{Research article}

Research articles report findings of original research in an accurate, clear, and concise manner. Findings must provide new insights that contribute to the growth of scientific knowledge.

\section{Research note}

Research notes report scientific results that are of particular importance and merit prompt publication. They are not a means to publish preliminary results. Research notes must be founded on sufficient data to sustain reliable and significant results.

\section{Review article}

Review articles provide a comprehensive and novel assessment of an important region of the world or a particular discipline in marine science. Strict criteria apply to this contribution category regarding quality, importance, potential controversies, general interest, and relevance for future research. These papers are generally submitted by invitation from the editor-in-chief, but exceptions may apply over previous consultation with the Editor.

\section{Comment (and reply)}

Comments are founded remarks to a previously published paper and are published together with a reply from the author(s) of the original paper. Articles and research notes are open for written discussion for up to one year following their original publication.

\section{What editors look for in a submission}

Editors and reviewers scrutinize every submission for ethical research and original sound science. They will not accept published material or manuscripts that are undergoing a submission process or are under consideration for publication at another journal.
- Editor en jefe: Un investigador reconocido responsable de seleccionar el contenido de la revista y de trabajar para alcanzar los objetivos de la revista.

- Editores asociados: Investigadores activos de diferentes partes del mundo que realizan estudios en diferentes campos de las ciencias del mar; ellos aseguran la calidad del contenido y coordinan el proceso de revisión.

- Revisores: Investigadores activos de diferentes partes del mundo, acreditados como contribuidores esenciales porque ayudan a garantizar la calidad de la ciencia descrita en los manuscritos.

- Editores internos: Editores de tiempo completo que se comprometen a garantizar la calidad de la publicación al asegurar la legibilidad, precisión y coherencia del idioma; ellos pulen el estilo, el formato y el aspecto de la revista.

\section{Qué publicar en Ciencias Marinas}

Las publicaciones en $\mathrm{CM}$ son principalmente reportes $\mathrm{y}$ notas de investigación original sobre todas las disciplinas del campo de ciencias marinas, las cuales incluyen pero no se limitan a la bioquímica marina, la oceanografía física, la biología pesquera, la ecología marina, la conservación, la genética y la acuacultura. CM también publica artículos de revisión y comentarios. Cuatro categorías de contribución son aceptadas para publicación:

\section{Artículo de investigación}

Los artículos de investigación reportan resultados de investigación original de manera precisa, clara y concisa. Los hallazgos deben proporcionar información nueva que contribuya al crecimiento del conocimiento científico.

\section{Notas de investigación}

Las notas de investigación reportan resultados científicos que son de particular importancia y ameritan una pronta publicación. No son un medio para publicar resultados preliminares. Estas notas deben contener datos suficientes para fundamentar resultados confiables y significativos.

\section{Artículos de revisión}

Los artículos de revisión proporcionan una evaluación comprensiva y novedosa de una región importante del mundo o de una disciplina particular de las ciencias del mar. Se aplican criterios estrictos pata esta categoría de contribución en cuanto a calidad, importancia, controversias potenciales, interés general y relevancia para investigaciones futuras. Generalmente, estas contribuciones se someten tras una invitación por parte del editor en jefe, pero se pueden aplicar excepciones mediante consultas previas con el Editor.

\section{Comentario (y respuesta)}

Los comentarios son observaciones fundadas a un artículo publicado anteriormente y son publicados junto con una respuesta del autor(es) del artículo original. Los artículos y las notas de investigación están abiertos a 
For acceptance in CM your submissions must comply with our writing and ethical guidelines. Editors may request permissions or evidence of author adherence to the 3Rs principles for use of animals in research (see National Centre for the Replacement, Refinement and Reduction of Animals in Research [2019] and related reads in Biblioagraphy). They will also enforce use of respectful, unbiased, and professional language for reporting research. We strive to provide our readers with succinct, accurate, and intelligible information, so our writing standards follow general principles assumed to be understood by the scientific community. While our readers are familiar with highly technical language, they may be unfamiliar with the standards of a specific field of research. Authors, when drafting your manuscript, please keep in mind our broad scientific audience.

\section{JOURNAL POLICIES}

$\mathrm{CM}$ is a fully bilingual, international, peer-reviewed journal that contains original research findings in all areas of marine science. With the aim of bringing sound science to a broad international audience, we defer all submissions to a blind peer-review process and publish all accepted material in English and Spanish. We endorse editorial and ethical policies that support ethical research. Failure to comply with any of our policies may lead to the declination of a submission at any stage of the publication process. Read through this section to learn more about the pillars supporting our journal.

\section{Focus and Outreach}

We aim to disseminate sound knowledge on marine life and its environment at an international level by publishing, via open access, original peer-reviewed papers on research in all disciplines in the field of marine science. Our goal extends to publishing authors from different parts of the world and to make their findings available to a wide community by publishing contents in two of the top spoken languages in the world, English and Spanish. We believe that by making these contents openly available in both languages we will breach language barriers in the science community and enable research findings to reach a wider audience, thus contributing to human and scientific development.

\section{Funding}

$\mathrm{CM}$ is funded by the Autonomous University of Baja California (Mexico). The National Council for Science and Technology (CONAYT, Mexico) occasionally provides funding through project grants.

\section{Publication frequency}

$\mathrm{CM}$ is published on a quarterly basis, at the end of March, June, September, and December. Special issues discusión escrita por hasta un año después de su publicación original.

\section{Qué buscan los editores en un manuscrito}

Los editores y los revisores analizan cada manuscrito para verificar que la ciencia sea original y ética. Ellos no aceptaran material ya publicado o manuscritos que estén en proceso de revisión o bajo consideración para publicación en otra revista.

Para ser aceptado en CM, tu manuscrito debe cumplir con nuestras directrices de escritura y ética. Los editores pueden solicitar permisos pertinentes o evidencia del apego de los autores a los principios de las 3Rs para el uso de animales en la investigación (ver National Centre for the Replacement, Refinement and Reduction of Animals in Research [2019] y lecturas similares en la bibliografía). También impondrán el uso de lenguaje respetuoso, imparcial y profesional en el reporte de una investigación. Nos esforzamos para proporcionar a nuestros lectores información sucinta, precisa e inteligible. Nuestros estándares de escritura, por tanto, se apegan a principios que presuntamente son entendidos por la comunidad científica. Si bien nuestros lectores están familiarizados con el lenguaje altamente técnico, pueden no estar familiarizados con los estándares de un campo de investigación en específico. Autores, al redactar su manuscrito, por favor, tomen en cuenta nuestra amplia audiencia científica.

\section{Políticas de la ReVista}

$\mathrm{CM}$ es una revista arbitrada internacional completamente bilingüe que contiene hallazgos originales de investigación en todas las áreas de las ciencias del mar. Con el objetivo de brindar ciencia sólida a una audiencia internacional amplia, remitimos todos los manuscritos a un proceso de revisión por pares mediante el sistema ciego y publicamos todo el material aceptado en inglés y en español. Respaldamos políticas editoriales y éticas que apoyan la investigación ética. El incumplimiento de nuestras políticas puede llevar a la declinación de manuscritos en cualquier etapa del proceso de publicación. Lee esta sección para conocer más sobre los pilares que sostienen a nuestra revista.

\section{Enfoque y alcance}

Nuestro objetivo es difundir conocimiento sólido sobre la vida marina y su ambiente a nivel internacional mediante la publicación, a través de acceso abierto, de artículos arbitrados originales sobre investigación en todas las disciplinas en el campo de ciencias marinas. Nuestra meta se extiende a publicar trabajos de autores de diferentes partes del mundo y hacer que sus hallazgos estén disponibles para una comunidad amplia mediante la publicación del contenido en dos de los idiomas más hablados en el mundo, el inglés y el español. Creemos que, al hacer que todo este contenido esté libremente disponible en ambos idiomas, podremos romper barreras de 
may be published upon request of recognized scientific institutions or organizations and after acceptance by the editorial board.

\section{Open access}

The articles published in Ciencias Marinas are available to the public immediately upon publication, and they can be freely downloaded, stored, and distributed so long as proper credit is attributed. Though we will soon be implementing Creative Commons licenses, the $\mathrm{CM}$ team still holds copyrights over all journal contents. Nevertheless, authors retain proprietary rights other than copyright, and the right to use all or part of their articles in future works of their own (not including duplicate publication) so long as proper credit is given.

\section{Writing style and format}

For general presentation matters, our in-house writing style and format generally follow authoritative international standards such as the International Organization for Standardization (ISO) and the International System of Units. Many of those standards are synthesized in the Scientific Style and Format: The CSE Manual for Authors, Editors, and Publishers (8th edition), the style guide published by the Council of Science Editors (CSE) and our primary reference. However, since $\mathrm{CM}$ is a bilingual journal, with contents issued in English and Spanish, our writing standards conform to individual language norms for matters concerning grammar and orthography. For English, we use standard American English and abide primarily by the Merriam-Webster Dictionary, the CSE style guide, and the Chicago Manual of Style (16th edition); for Spanish, we primarily abide by the dictionary and language standards published by the Real Academia Española. Please keep this in mind if you are considering CM as your publication platform.

\section{Submission policy}

By submitting a manuscript to CM, you acknowledge and/ or declare that you are submitting to a bilingual, international, open-access journal and that your manuscript

- is of your authorship (if one author) or was equally elaborated by all authors (if more than one author) and that you have the full authority to submit it to $\mathrm{CM}$

- is drafted in English or Spanish

- reports original, ethical research performed by you

- has not been published in another journal, book, or any other form, except in the form of a conference abstract, a part of a lecture, or an academic thesis

- is not under consideration for publication elsewhere

- complies with CM standards lenguaje en la comunidad científica, hacer que los hallazgos de investigación alcancen una mayor audiencia y, por tanto, contribuir con el desarrollo humano y científico.

\section{Financiamiento}

CM es financiada por la Universidad Autónoma de Baja California (México). El Consejo Nacional de Ciencia y Tecnología (CONACYT, México), ocasionalmente, proporciona fondos mediante la subvención de proyectos.

\section{Frecuencia de publicación}

$\mathrm{CM}$ es publicada trimestralmente, a finales de marzo, junio, septiembre y diciembre. Los números especiales pueden ser publicados bajo solicitud de instituciones u organizaciones científicas reconocidas y después de la aprobación del cuerpo editorial.

\section{Acceso abierto}

Los artículos publicados en CM están disponibles para el público inmediatamente en cuanto se publican, y pueden ser descargados, almacenados y distribuidos libremente siempre y cuando se otorgue el crédito debido. Aunque pronto estaremos implementando las licencias Creative Commons, el equipo CM aún retiene los derechos de autor de todo el contenido de la revista. Sin embargo, los autores retienen derechos de propiedad, salvo los derechos de autor, y el derecho de utilizar todo o parte de su artículo en sus futuros trabajos (no inclusa la publicación duplicada) siempre y cuando otorguen el crédito apropiado.

\section{Estilo y formato de redacción}

Para cuestiones generales de presentación, nuestro estilo y nuestro formato interno de redacción generalmente se apegan a estándares internacionales autorizados tales como los de la Organización Internacional de Normalización (ISO, por sus siglas en inglés) y el Sistema Internacional de Unidades. Muchos de estos estándares se sintetizan en el Scientific Style and Format: The CSE Manual for Authors, Editors, and Publishers (8va edición), la guía de estilo publicada por el Consejo de Editores de la Ciencia (CSE, por sus siglas en inglés) y nuestra referencia principal. Sin embargo, ya que CM es una revista bilingüe, cuyo contenido es emitido en inglés y en español, nuestros estándares de redacción se ajustan a las normas individuales de gramática y ortografía de cada idioma. Para la versión en inglés utilizamos el inglés americano estándar y nos apegamos al diccionario de Merriam-Webster, a la guía de estilo del CSE y al Chicago Manual of Style (16va edición); para la versión en español, nos apegamos al diccionario y a los estándares de lenguaje publicados por la Real Academia Española. Por favor tengan esto presente si están considerando a CM como su plataforma de publicación. 
- can be declined anytime during the editorial process if it fails to comply with CM standards and policies

- will be submitted to a blind peer-review process

- will not automatically be accepted for publication

- may be screened for duplication at any time during the editorial process

- if accepted, has every author's approval for publication in $\mathrm{CM}$

- if accepted for publication, needs to be translated to either English or Spanish, depending on language of submission, and that the translation will be provided by either you or, if you accept to pay the corresponding fees, by our in-house translator*

- if accepted for publication, will be edited along with all its components (e.g., figures, tables, appendices, supplementary material) by our in-house editors to conform to $\mathrm{CM}$ writing, reporting, and presentation guidelines

- if accepted, will be published and will be freely available in its final published form and in the final translated version to the general public under our open-access policies.

- While we do promote inclusion and ensure that all manuscripts are processed fairly and equally, the CM team reserves the right to decline any submission that does not meet our guidelines or policies.

*Upon author request.

\section{Publication ethics}

At $\mathrm{CM}$ we support research integrity and discourage unethical practices and research misconduct by editors, reviewers, and authors. All contributions must be original papers. Plagiarism, duplicate publication, redundant publication, falsification and fabrication, and inappropriate figure manipulation are strongly discouraged. If such unaccepted malpractices are suspected in a submission at any stage of the editorial process or after publication, we will take actions necessary and even decline the submission or retract already-published material. When you submit a paper to CM, you are expected to abide by standard publication ethics.

For more information on publication ethics and research integrity, you may consult the Committee on Publication Ethics (also known as COPE) and the CSE's White Paper on Promoting Integrity in Scientific Journal Publications.

\section{Originality}

Originality means that the submission has not been published elsewhere except in the form of an abstract or as part of a lecture or an academic thesis. Submitting uncredited material that is not your own is unaccepted. We briefly describe plagiarism and self-plagiarism, but more detailed information can be found in the CSE'S White Paper on

\section{Política de envío}

Al someter un manuscrito a $\mathrm{CM}$, estás reconociendo $\mathrm{y} / \mathrm{o}$ declarando que estás sometiendo tu manuscrito a una revista bilingüe internacional de acceso abierto y que tu manuscrito

- es de tu autoría (si se trata de un autor) o fue elaborado equitativamente por todos los autores (si se trata de más de un autor) y que tienes toda la autoridad de someterlo a CM

- está redactado en inglés o en español

- reporta investigación original y ética realizada por ti

- no ha sido publicado en otra revista, otro libro o ningún otro formato, excepto en forma de un resumen de congreso, una plática/clase o una tesis académica

- no está siendo considerado para publicación en otra parte

- cumple con los estándares de CM

- puede ser declinado en cualquier momento durante el proceso si no cumple con nuestros estándares y nuestras políticas

- será sometido a un proceso de revisión por pares bajo el sistema ciego

- no será aceptado automáticamente para su publicación

- podrá ser examinado para descartar duplicidad en cualquier momento del proceso editorial

- si es aceptado, tiene la autorización de todos los autores para ser publicado en CM

- si es aceptado para su publicación, necesita ser traducido al inglés o al español, dependiendo del idioma en el cual fue enviado, y que la traducción será proporcionada por usted o, si acepta todos los cargos, por nuestro traductor interno*

- si es aceptado para su publicación, será editado junto con todos sus componentes (e.g., figuras, tablas, apéndices, material suplementario) por nuestros editores internos para ajustarlo a los lineamientos de redacción, reportaje de información y presentación de CM

- si es aceptado para su publicación, estará libremente disponible al público general en su formato final de publicación y en su versión traducida bajo nuestras políticas de acceso abierto

- Aunque promovemos la inclusión y nos aseguramos que todos los manuscritos sean procesados de manera justa y con igualdad, el equipo de CM se reserva el derecho de rechazar cualquier manuscrito que no cumpla con nuestros lineamientos o políticas de envío.

*Bajo solicitud del autor.

\section{Publicación ética}

En CM apoyamos la integridad en la investigación y desalentamos las prácticas no éticas y las malas conductas por parte de los editores, los revisores y los autores. Todas las contribuciones deberán ser artículos originales. El plagio, la publicación duplicada, la publicación redundante, la falsificación y fabricación, y la manipulación inapropiada de figuras 
Promoting Integrity in Scientific Journal Publications and the COPE website.

Plagiarism is the act of taking and using someone else's work, be it wording, figure, table, data, or other materialized idea, without authorization and without granting rightful attribution. Self-plagiarism (also duplicate publication) is the act of republishing material without acknowledgment of the original source. Any form of plagiarism is inadmissible for CM publications. All manuscripts accepted for publication will be screened for duplicity before publication. Manuscripts found to contain plagiarized material may be declined at any stage during the publication process, even after acceptance. If plagiarism is detected after publication, the published paper will be retracted. In any case involving plagiarized material, it is our ethical obligation to notify the author's institution and any other party being compromised.

\section{Falsification and fabrication}

Falsification and fabrication are forms of research misconduct that will not be tolerated in any way. Detection of such misconduct will be notified to the corresponding authorities and the manuscript can be rejected or, if already published, retracted.

\section{Animal welfare}

We advocate for zero unnecessary use of animals in research and for ethical use in studies where advancement of science calls for the use of animals. Editors may request permissions or evidence of author adherence to the 3Rs principles for use of animals in research. For more on the 3 Rs principles, we refer you to the following bibliography: National Centre for the Replacement, Refinement and Reduction of Animals in Research (2019) and the International Council for Laboratory Animal Science (2015).

\section{Competing interests}

Authors are asked to send a statement clearing any potential conflict of interest regarding their manuscript. Potential conflicts of interest must be resolved before publication. You must let the editor know of any competing interest (e.g., financial support that may have influenced your research, potentials reviewers that could be involved in any way in your research). The editor may contact you and any conflicting or influential party to resolve any interest dispute. If you have no competing interests to declare, you must state this in your manuscript. Declarations of competing interests may be published in the corresponding paper.

\section{Authorship}

Authors are the individuals who created the reported work and are publicly accountable for it. By created we mean son prácticas sumamente desaconsejadas. Si se sospecha de tales prácticas no aceptadas en un manuscrito en cualquier momento del proceso editorial o después de la publicación, tomaremos las medidas necesarias e incluso rechazaremos el manuscrito o retiraremos el material ya publicado. Al enviar un documento a $\mathrm{CM}$, se espera que cumplas con los estándares de publicación ética.

Para obtener más información sobre la publicación ética y la integridad en la investigación, puedes consultar al Comité de Ética en la Publicación (también conocido como COPE) y el CSE's White Paper on Promoting Integrity in Scientific Journal Publications.

\section{Originalidad}

Originalidad significa que el manuscrito sometido a $\mathrm{CM}$ no ha sido publicado en otra parte excepto en forma de resumen o como parte de una plática/clase o tesis académica. El someter material sin atribuciones que no es tuyo no es una práctica aceptada. Aquí describimos brevemente lo qué es el plagio y el autoplagio, pero puedes encontrar más información detallada en el CSE's White Paper on Promoting Integrity in Scientific Journal Publications y la página web de COPE.

Plagio es el acto de tomar y utilizar el trabajo de alguien más, ya sea palabras, figuras, datos o cualquier otra idea materializada, sin su autorización y sin otorgar la atribución apropiada. Autoplagio (también conocido como publicación duplicada) es el acto de publicar nuevamente material ya publicado sin reconocer a la fuente original. Cualquier forma de plagio es inadmisible para las publicaciones de CM. Todos los manuscritos aceptados para publicación serán examinados digitalmente antes de la publicación para verificar que no contengan duplicidad. Los manuscritos que contengan material plagiado pueden ser rechazados en cualquier etapa del proceso de publicación e incluso después de ser aceptados. Si detectamos plagio después de la publicación, el artículo publicado será retractado. En cualquier caso que involucre material plagiado, es nuestra obligación ética notificar a la institución del autor y cualquier otra entidad comprometida.

\section{Falsificación y fabricación}

La falsificación y la fabricación son malas conductas de investigación que no serán toleradas de ninguna manera. La detección de tales conductas será notificada a las autoridades correspondientes y el manuscrito podrá ser rechazado o, si ya fue publicado, retractado.

\section{Bienestar animal}

Apoyamos la acción de cero uso innecesario de animales en la investigación y el uso ético en aquellos estudios que necesiten utilizar animales para el avance de la ciencia. Los editores podrán solicitar los permisos pertinentes o evidencia de que el autor se apegó a los principios de las 3Rs para el uso 
designing and conducting the study and/or interpreting the results. Individuals warrant authorship when they have made a substantial intellectual contribution to the study and the manuscript. Give authorship to those who have the merit and as they merit.

Avoid granting authorship to individuals who did not make a considerable input to the paper. Guest-authorship (attributing authorship to an individual who does not merit the title) and ghost authorship (not crediting as author an individual who merits the title) are unethical practices and are strongly discouraged. Editing a figure does not merit authorship. You may credit individuals who made some contribution (e.g., data collecting, text or figure editing, providing study material, etc.), but not so much as to warrant authorship, in the acknowledgments section. For more on authorship, see the CSE's White Paper on Promoting Integrity in Scientific Journal Publications.

The contribution made by each person credited as author must be stated in a letter.The order in which the authors are listed in the original submission should remain unchanged. Any change in this order must be done under a formal written request to the editor-in-chief. This request must be signed by all contributing authors and explain the reasons for the change.

\section{Peer review}

All manuscripts submitted for consideration in $\mathrm{CM}$ undergo a blind peer-review process. The peer-review process is designed to ensure all published material is grounded on sound original science. It should enrich scientific discussion with positive feedback. CM encourages and enforces positive, impartial, and respectful feedback from reviewers to authors and from authors to reviewers.

Briefly, all submissions are sent out for blind review by one of our associate editors or directly by the editor, depending on the subject area of the reported research. After at least two external peers have returned the manuscript with reviews, the associate editor will analyze the reviews and send a recommendation to the editor. All final decisions are made by the editor-in-chief.

\section{Fees}

Publication fees:

As of January 2017, there are no publication fees.

Translation fees:

\$15.0 USD per double-spaced Word page.

Other fees:

$\$ 10.0$ USD per double-spaced Word page for editing of poor translations.

\$7.0 USD per galley page that needs to be restructured due to requested changes after the galley. de animales en la investigación. Para obtener más información sobre los principios de las 3 Rs te referimos a la siguiente bibliografía: National Centre for the Replacement, Refinement and Reduction of Animals in Research (2019) y International Council for Laboratory Animal Science (2015).

\section{Intereses en competencia}

Pedimos que los autores envíen una declaración donde acierten que no existen conflictos de intereses con respecto a su manuscrito. Los potenciales conflictos de intereses deben quedar resueltos antes de la publicación. Debes notificar al editor si existe algún interés en competencia (e.g., apoyo financiero que pudo haber influido en tu investigación, revisores potenciales que pudieran estar involucrados de alguna manera en tu investigación). Para resolver disputas de intereses, el editor puede contactarte a ti y a cualquier individuo que pueda influir o tener algún conflicto. Si no tienes conflictos de intereses que declarar, debes declararlo en tu manuscrito. Las declaraciones de intereses en competencia podrán ser publicadas en el artículo correspondiente.

\section{Autoría}

Autores son aquellos individuos que crearon el trabajo reportado y que son públicamente responsables de este. Por crearon queremos decir diseñaron y condujeron el estudio y/o la interpretación de los resultados. Las personas que merecen autoría son aquellas que han hecho una contribución intelectual sustancial al estudio y al manuscrito. Otorga la autoría apropiada a aquellos que lo ameriten y cómo lo ameriten.

Evita regalar autoría a individuos que no hicieron una contribución considerable al artículo. La autoría regalada (autoría atribuida a individuos que no merezcan el título) y la autoría fantasma (autoría no atribuida a individuos que sí merezcan el título) son prácticas no éticas y vehementemente desaconsejadas. El editar figuras no amerita autoría. Puedes dar crédito a individuos que hicieron alguna contribución (e.g., recolectar datos, editar texto o figuras, proveer material de estudio, etc.), pero no la suficiente para merecer autoría, en la sección de agradecimientos. Para obtener más información sobre autoría, ve el CSE's White Paper on Promoting Integrity in Scientific Journal Publications.

En tu envío debes incluir una carta donde quede declarada la contribución de cada persona acreditada como autor. El orden en que se enlisten los autores en el manuscrito original siempre debe mantenerse igual. Cualquier cambio en este orden debe solicitarse formalmente de manera escrita al editor en jefe. Esta petición debe ser firmada por todos los autores y debe llevar una explicación de las razones para el cambio.

\section{Arbitraje}

Todos los manuscritos sometidos para ser considerados en $\mathrm{CM}$ pasan por un proceso de arbitraje tipo ciego. El proceso 


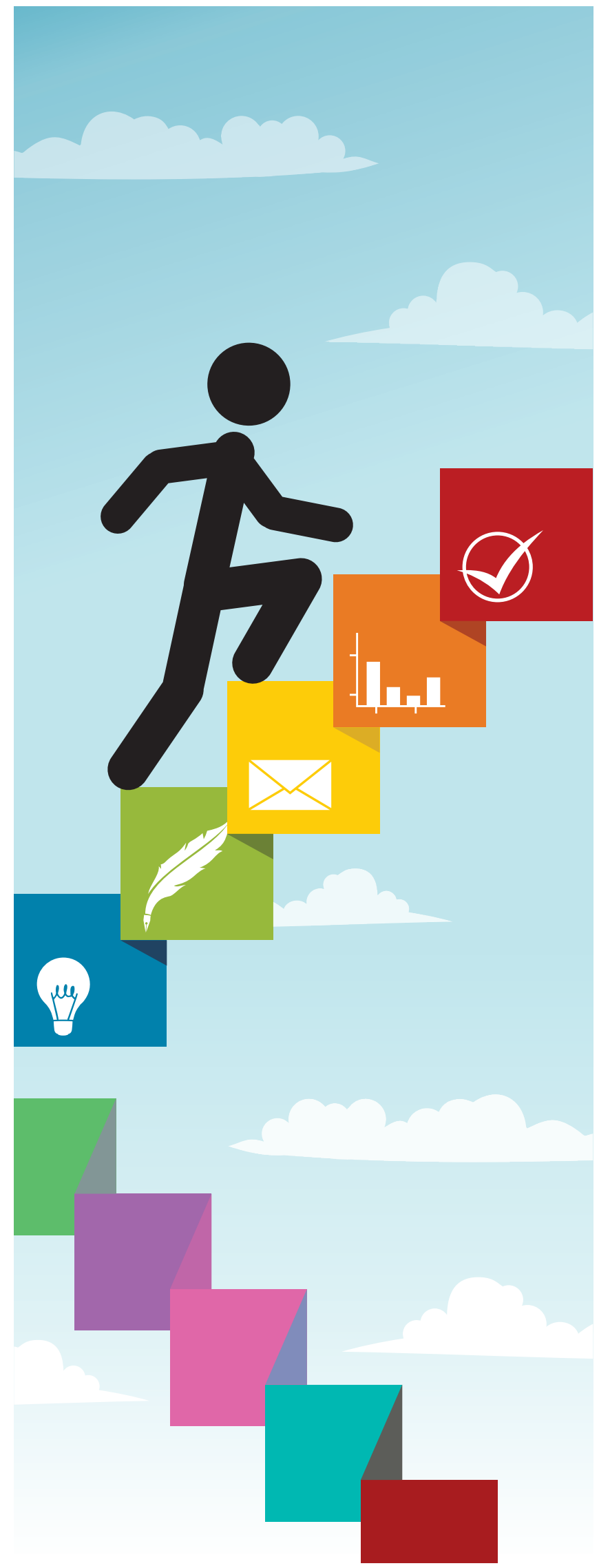

de arbitraje está diseñado para asegurar que todo el material publicado está basado en ciencia que es original y sólida. Debe enriquecer la discusión científica con retroalimentación positiva. CM exhorta y exige la retroalimentación positiva, imparcial y respetuosa de los revisores a los autores y de los autores a los revisores.

Brevemente, todos los manuscritos son enviados a una revisión por pares tipo ciego por uno de nuestros editores asociados o directamente por el editor, dependiendo del área de estudio de la investigación reportada. Después de que al menos dos revisores hayan devuelto el manuscrito con sus observaciones, el editor asociado analiza las revisiones y envía su recomendación al editor. Toda decisión definitiva la toma el editor en jefe.

\section{Costos}

Costo de publicación:

Desde enero de 2017, no cobramos cuotas de publicación.

Costo de traducción:

$\$ 15.0$ dólares (EUA) por página Word a doble espacio.

Otros costos:

\$10.0 dólares (EUA) por página Word a doble espacio por la edición de traducciones de mala calidad.

\$7.0 USD dólares (EUA) por página de galera que necesite reestructuración debido a los cambios solicitados en la galera.

\section{ENVÍO DEL MANUSCRITO}

El enviar o someter un manuscrito implica que el trabajo descrito no ha sido publicado previamente (excepto en la forma de un resumen o como parte de una conferencia o tesis académica), que no está siendo considerado en otra parte, que su publicación ha sido aprobada por todos los autores y todas las autoridades involucradas en el trabajo y que, si es aceptado, no será publicado en la misma forma en otra parte sin la atribución apropiada.

Aquí describimos sólo el proceso de envío. Asegúrate que tu manuscrito se apegue a nuestras políticas editoriales y a nuestros lineamientos para la preparación de manuscritos antes de que comiences el proceso de envío.

\section{Proceso general de envío}

El proceso general de envío para publicar en $\mathrm{CM}$ puede ser resumido en cinco pasos:

1. Ingresa a tu cuenta de usuario directamente a través de nuestra página web. Si aún no tienes una cuenta, puedes crearla sin costo alguno.

2. Envía el archivo de tu manuscrito en formato de documento portátil (PDF) para el proceso de revisión inicial (ve las directrices para el envío inicial). 


\section{MANUSCRIPT SUBMisSion}

Submission of a manuscript implies that the work described has not been previously published (except in the form of an abstract or as part of a published lecture or academic thesis), that it is not under consideration elsewhere, that its publication is approved by all authors and authorities involved in the work, and that, if accepted, it will not be published elsewhere in the same form without proper attribution.

Here, we describe only the submission process. Make sure your manuscript conforms to our journal policies and manuscript preparation guidelines before you begin the submission process.

\section{General submission process}

The overall process for publishing with $\mathrm{CM}$ can be summarized in five steps:

1. Sign in to your user account directly through our website. If you do not have one, you can create one free of charge.

2. Submit your manuscript file in a portable document format (PDF) for the initial review process (see guidelines for initial submission).

3. Review editor feedback and editorial decision.

4. Submit the Microsoft Word or RTF file of the final accepted version of your manuscript for the editorial production process (see guidelines for final submission).

5. Review and return the revised preliminary proof and the galley of your manuscript for publication.

Before you make a submission, be sure to read through the manuscript preparation guidelines. Manuscripts may be declined for publication before or after the review process if they fail to fit the scope of the journal, lack originality, show flaws in methodology, lack coherence, fail to abide by our ethical policies, and/or fail to meet our journal guidelines.

If your manuscript is accepted for publication, please follow the guidelines for final submission.

You will be appointed deadlines for each task in the general process. Failure to meet the deadlines may cause delays in publication or even submission declination, and you will have to begin a new submission process.

\section{Initial submission}

Log in to your user account. If you do not already have one, you can create one free of charge.

In your user homepage, follow the five easy steps in Start a New Submission. Before submitting, review the manuscript preparation guidelines. Submit your manuscript in English or Spanish in a single PDF file. This file should include figures and tables at the end, if any. Please do not insert tables and
3. Revisa la retroalimentación de los editores y la decisión editorial.

4. Envía el archivo Microsoft Word o RTF de la versión final aceptada de tu manuscrito para el proceso de producción (ver las directrices para el envío final).

5. Revisa y devuelve la primer prueba editada por CM y la prueba final (galera) de tu manuscrito para el paso final de publicación.

Antes de enviar tu manuscrito, asegúrate de leer bien las directrices para la preparación de manuscritos. La publicación de los manuscritos puede ser declinada antes o después del proceso de revisión si estos no cumplen con el enfoque de la revista, carecen de originalidad, muestran defectos en la metodología, carecen de coherencia, no se apegan a nuestras políticas de ética y no se ajustan a nuestros lineamientos editoriales.

Si tu manuscrito ha sido aceptado para su publicación, por favor, sigue las directrices para el envío final.

Se te asignaran fechas límite para cada tarea del proceso general. La falta de cumplimiento de estas fechas límite puede causar retrasos en la publicación y hasta la declinación de un envío, y tendrás que comenzar un nuevo proceso de envío.

\section{Envío inicial}

Ingresa a tu cuenta de usuario. Si aún no tienes una, puedes crear una sin costo alguno.

En tu página de usuario, sigue los cinco fáciles pasos que se encuentran en la opción Enviar un artículo. Antes de enviar o someter un manuscrito, revisa las directrices para la preparación de manuscritos. Envía tu manuscrito redactado en inglés o en español en un solo archivo PDF. Este archivo debe incluir las figuras y las tablas al final si tu manuscrito las tiene. Por favor, no insertes las figuras ni las tablas en el texto corrido. Además, anexa un archivo con la información (nombre de institución, dirección, número de teléfono y correo electrónico) de hasta cinco revisores potenciales. Estos revisores no deben tener alguna asociación con la institución del autor y al menos dos de estos cinco individuos debe pertenecer a una institución diferente de la institución del autor. En un archivo aparte, incluye también una declaración donde se describa la contribución de cada autor. Si existe algún conflicto de interés exprésalo en una carta aparte y si no lo existe, por favor, exprésalo en la primer página de tu manuscrito.

Tu manuscrito será asignado a un editor asociado, quien velará el proceso de revisión.

Por favor toma en cuenta que todos los manuscritos que no se apeguen a nuestros lineamientos no avanzarán al proceso de arbitraje (revisión por pares).

\section{Proceso de arbitraje}

Todos los manuscritos sometidos como artículos de revisión, notas de investigación o comentario/respuesta pasan 
figures in the running text. Also, attach a file containing the names and corresponding information (institution, address, phone number, and e-mail) of up to five potential reviewers. These reviewers should not be associated to the author's institution and at least two of these five individuals must belong to an institution in a country different from that of the author's institution. On a separate file include a statement describing the contribution made by every author. State any competing interest on a separate letter, and if none exists please state it so on the title page of your manuscript.

Your manuscript will be assigned to an associate editor, who will handle the review process.

Please note that all manuscripts that do not meet our guidelines will not be processed for peer review.

\section{Review process}

All manuscripts submitted as research articles, research notes, review articles, or comment/reply notes undergo a blind peer-review process. During the review process, your manuscript will be sent to at least two researchers from a related field who will review your work. Feedback during this process is highly valuable. In the event your manuscript is accepted with revisions, make the revisions as appropriate and upload your revised file and a cover letter with a reply to the reviewer comments. If the reviewers or the associate editor deem it necessary, a second review round may follow. After all the reviews have been turned in and at least 2 reviewers have concluded the same judgment, the associate editor will give his/her recommendation to the editor.

\section{Editorial decision}

After the review process is complete, the editor-inchief will take into account the recommendations from the associate editor and the reviewers. You will then be notified of the Editor's decision whether your submission has been accepted:

- Accepted: Your manuscript has been accepted as is. You can immediately send your final submission.

- Accepted with revisions: Make the appropriate revisions by or before the deadline and upload your revised file. The Editor will determine if your manuscript is ready for publication and you may then send your final submission.

- Rejected: Your manuscript might not fit the journal's scope or contents, might not comply with the journal's guidelines, or might not have enough evidence to support your findings. You are welcome to start a new submission after attending these matters.

Remember to meet the deadlines to avoid delaying your publication or having to start a new submission process. por un proceso de revisión por pares tipo ciego. Durante el proceso de revisión, tu manuscrito será enviado a al menos dos investigadores de disciplina afín para que revisen tu trabajo. La retroalimentación durante este proceso es invaluable. En caso de que tu manuscrito sea aceptado con revisiones, has las correcciones apropiadas y envía tu archivo revisado con una carta que incluya las respuestas a los comentarios de los revisores. Si los revisores o el editor asociado lo juzgan necesario, puede haber una segunda ronda de revisiones. Después de que se hayan entregado todas las revisiones y al menos dos revisores hayan concluido una misma opinión, el editor asociado enviará su recomendación al editor.

\section{Decisión editorial}

Después de que se haya completado el proceso de revisión, el editor en jefe tomará en cuenta las recomendaciones de los editores asociados y de los revisores. Después, recibirás una notificación de la decisión del editor si tu manuscrito fue aceptado, aceptado con revisiones o rechazado:

- Aceptado: Tu manuscrito ha sido aceptado tal como está. Puedes proceder inmediatamente a tu envío final.

- Aceptado con revisiones: Haz las correcciones pertinentes a la fecha de entrega, o antes, y envía tu archivo corregido. El editor determinará si tu manuscrito está listo para publicar y tú podrás entonces proceder al envío final.

- Rechazado: Es posible que tu manuscrito no se ajusta al enfoque de la revista, no cumple con las directrices de la revista o no presenta suficiente evidencia para apoyar tus hallazgos. Tú puedes empezar un nuevo proceso de envío después de resolver estos asuntos.

Recuerda siempre cumplir con las fechas de entrega para evitar algún retraso en tu publicación o el tener que comenzar un nuevo proceso de envío.

\section{Envío final}

Una vez que tu manuscrito haya sido aceptado, envía el archivo Microsoft Word o RTF de la versión final aceptada de tu manuscrito y la traducción correspondiente*. Si tu manuscrito contiene figuras, debes enviar los archivos editables por separado.

Carga la versión final aceptada de tu manuscrito a la sección apropiada en la página principal de tu cuenta en la plataforma de la revista.

*En CM, podemos traducir al inglés o al español los manuscritos aceptados para publicación en $\mathrm{CM}$, pero a cuenta del autor (ver cargos por traducción). Puedes enviar tu propia traducción o solicitar nuestro servicio de traducción. Por favor indica tu decisión al momento de hacer tu envío final. Si tu traducirás tu manuscrito, tendrás una 


\section{Final submission}

Once your manuscript has been accepted, send the Microsoft Word or RTF file of the accepted version of your manuscript and the corresponding translation*. If your manuscript contains any figures, you should send the editable files separately.

Upload the final accepted version of your manuscript to the appropriate section in your user home page in the journal platform.

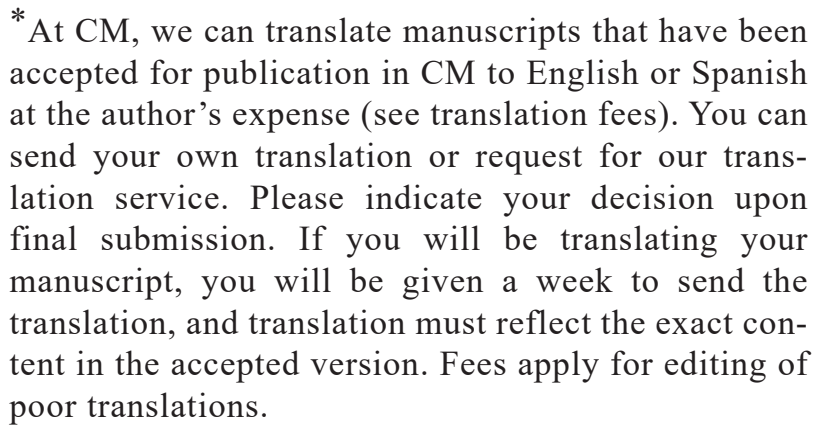

\section{Proofs}

Before publication, you will receive a preliminary proof and a galley of your manuscript for corrections. Review and send back each proof with your comments. For the galley, corrections to the text other than typesetting errors must be kept to a minimum level. Major changes here will be done at the author's expense. Proofs should be returned timely via our journal platform or e-mail.

\section{Publication}

You will receive a copyright form, which you must sign and return. Once we receive the reviewed galley and the signed copyright, your manuscript will be ready for publication.

Publications will appear in the printed and electronic versions of the journal. The printed form is reserved for subscribed universities and indexing companies. You can freely download the electronic version of any article in the journal from our website.

\section{MANUSCRIPT PREPARATION}

For all submission types, use clear, concise, and consistent language. You may submit your manuscript in English or Spanish in most cases*. Use doublespaced pages $(11.0 \times 8.5$ inches $)$ and Times New Roman type (12-point font). Number each page of the manuscript consecutively. Include number lines throughout your manuscript, starting from the title page. See specifications for each submission type in the Manuscript preparation for initial submission section, which follows this section. semana adicional para enviar la traducción, y la traducción debe reflejar el contenido exacto en la versión final aceptada. Se aplican cargos por edición de traducciones de mala calidad.

\section{Pruebas}

Antes de la publicación, recibirás una prueba preliminar y una prueba final (galera) de tu manuscrito para revisar y solicitar correcciones. Revisa y regresa cada prueba con tus comentarios. Para la galera, las correcciones al texto que no sean de composición tipográfica deben mantenerse al mínimo. Los cambios mayores en esta etapa se efectuarán con cargo al autor. Las pruebas deben ser devueltas a tiempo a través de la plataforma de nuestra revista o por correo electrónico.

\section{Publicación}

Recibirás un formato de cesión de derechos de autor, el cual debes firmar y devolver. Una vez que hayamos recibido la galera revisada y el formato firmado, tu manuscrito quedará listo para ser publicado.

\section{Preparación del manuscrito}

Para todos los tipos de envío, utiliza lenguaje claro, conciso y consistente. Puedes enviar tu manuscrito redactado en inglés o en español*. Utiliza páginas $(11.0 \times 8.5$ pulgadas $)$ a doble espacio y tipo de fuente Times New Roman (12 puntos). Numera cada página de tu manuscrito de forma consecutiva. Incluye números de línea en todo tu manuscrito, desde la página titular hasta el final. Ve las especificaciones para cada tipo de envío en la sección Preparación del manuscrito para el envío inicial, que es la sección que sigue.

En general, tu manuscrito debe incluir, en este orden, la página titular, el resumen y las palabras clave, el cuerpo principal del texto, la lista de referencias y, si aplica, la lista de pies de figura seguida de la lista de tablas y las figuras correspondientes. No admitimos una sección separada para conclusiones. Sin embargo, puedes incluir tu conclusión en el último párrafo de la discusión. Las listas sistemáticas no son admitidas para publicación.

* La página titular, el resumen y las palabras clave deben ser enviadas tanto en inglés como en español, aún si solicitas nuestro servicio de traducción. Los artículos de revisión sólo pueden ser enviados en inglés.

\section{Preparación del manuscrito para el envío inicial}

Para la etapa del envío inicial, somete el archivo PDF de tu manuscrito. El tamaño del archivo no debe exceder de 2 MB. Dependiendo del tipo de envío, asegúrate de haber seguido las directrices para la presentación del manuscrito apropiadas antes de enviar tu archivo. 
In general, your manuscript should include, in the following order, the title page, abstract and key words, main body of the text, list of references, and, if applicable, the list of figure captions followed by the list of tables and the corresponding figures. A main entry for conclusions is strongly discouraged. You may, however, add your conclusion in the last paragraph of the discussion. Systematic lists will not be accepted for publication.

*The title, abstract, and key words must be sent in English and Spanish even if you request for our translation service. We only accept English for review articles.

\section{Manuscript preparation for initial submission}

For the initial submission stage, submit the PDF file of your manuscript. File size must be less than $2 \mathrm{MB}$. Depending on the type of submission, make sure you followed the manuscript presentation guidelines accordingly before you send your file.

\section{Type of submission}

1. Research articles: Maximum 25 pages, including title page, body of manuscript, cited literature, list of figure captions, tables, and figures. Longer articles will be published on rare occasions and at the editor's criteria. Submit in English or Spanish.

2. Research notes: Maximum 10 pages. Submit in English or Spanish.

3. Review articles: Maximum 30 pages. Submit in English only.

4. Comments (and reply): Maximum 5 pages. Abstract and key words are not necessary. The author of the original paper will be given the opportunity to present a reply. The comments and reply will then be published together. Papers are open for written discussion for up to one year following their original publication. Submit in English or Spanish.

\section{Style and format}

For general science and writing presentation matters, our style and format follow international standards, most of which are summarized in the CSE style and format manual (Scientific Style and Format: The CSE Manual for Authors, Editors, and Publishers; 8th edition) and the Chicago Manual of Style. The former is our primary guide. Our writing standards conform to the proper language norms (English/ Spanish) for matters concerning grammar and orthography. For English, use standard American English and refer to the Merriam-Webster Dictionary, the CSE style guide, and the Chicago Manual of Style (16th edition); for Spanish, refer to the dictionary and language standards published by the Real Academia Española.
Tipo de envío

1. Artículo de revisión: Máximo 25 páginas, incluyendo la página titular, el cuerpo del manuscrito, la lista de referencias, la lista de pies de figura, las tablas y las figuras. Se podrán publicar artículos más extensos sólo en algunas ocasiones y al criterio del editor. Puedes enviarlo en inglés o en español.

2. Nota de investigación: Máximo 10 páginas. Puedes enviarla en inglés o en español.

3. Artículo de revisión: Máximo 30 páginas. Puedes enviarlo sólo en inglés.

4. Comentario (y respuesta): Máximo 5 páginas. No es necesario incluir resumen y palabras clave. El autor del artículo original tendrá la oportunidad de presentar una respuesta al comentario. Los comentarios y las respuestas se publican juntos. Los artículos están abiertos a discusión hasta un año después de su publicación original. Puedes enviarlos en inglés o en español.

\section{Estilo y formato}

Para cuestiones generales de presentación científica y escrita, nuestro estilo y formato siguen estándares internacionales, la mayoría de los cuales están resumidos en el manual de estilo y formato del CSE (Scientific Style and Format: The CSE Manual for Authors, Editors, and Publishers; 8th edition) y el Chicago Manual of Style. El primero es nuestra guía principal. Nuestros estándares de redacción se apegan a las normas propias de cada idioma (inglés/español) para cuestiones de gramática y ortografía. Para el inglés, utiliza inglés americano estándar y básate en el Merriam-Webster Dictionary, el manual de estilo y formato del CSE, y el Chicago Manual of Style (16va edición); para el español, básate en el diccionario y las normas de lenguaje publicados por la Real Academia Española.

\section{Presentación del manuscrito}

En general, todo tipo de envío excepto los comentarios y las respuestas deben incluir las entradas que abajo se mencionan. Los comentarios y las respuestas deben contener la página titular y comentarios sólidos sobre la publicación a la que se refieren.

Si tu manuscrito cumple con las entradas que abajo se mencionan, entonces está listo para que lo envíes:

\section{- Página titular}

La información en esta sección es la que los motores de búsqueda utilizan como base para canalizar la información de tu trabajo. La página titular debe incluir los siguientes elementos:

\section{- Título}

Los títulos muy extensos no son aconsejados. Un título dice todo sobre un manuscrito. El título debe describir 


\section{Manuscript presentation}

In general, all submission types except for comments and replies should include the entries listed below. Comments and replies should contain the title page and sound remarks on the appointed publication.

If your manuscript complies with the entries and standards mentioned below, then it is ready for submission:

\section{- Title page}

The information in this section is what search engines use as basis to get the word out about your work. The title page should include the following elements:

\section{- Title}

Extensive titles are discouraged. A title succinctly says all about your paper. The title should concisely and explicitly describe the contents of your work. Indexes and other search engines use the words in the title when searching for contents, so be sure to choose your words wisely.

Include the English and Spanish version of the title of your work. The title, at the top of the page, is not be underlined and should not include references or geographic coordinates. If a species name is included, do not include the attribution here; however, the corresponding class, order, family, etc., may be given in parentheses.

Use sentence style capitalization: capitalize only the first letter of the title and proper nouns (if any).

- Author name(s)

Use the exact spelling of your name as in all your publications. Mention the given name(s) first and then the surname(s). Place an asterisk next to the name of the corresponding author.

For author names with more than one surname, use a hyphen between surnames. Avoid using a period when abbreviating a middle name. Separate author names by a comma and do not use and before the last author. Place superscript numbers next to the author names to indicate the corresponding affiliation; superscript numbers must appear in ascending numerical order from left to right upon first mention. Consider the following examples:

\section{YES}

James Smith ${ }^{1}$, María López-Ruíz ${ }^{2}$, Sarah Parks ${ }^{3}$ James Smith ${ }^{1}$, María López-Ruíz ${ }^{1}$, Sarah Parks ${ }^{2}$ James Smith ${ }^{1}$, María López-Ruíz ${ }^{1,2}$, Sarah Parks ${ }^{3}$ James Smith ${ }^{1}$, María López-Ruíz ${ }^{2,3}$, Sarah Parks ${ }^{2}$

\section{NO}

James Smith², María López-Ruíz ${ }^{1}$, and Sarah Parks ${ }^{3}$ James Smith ${ }^{1}$, María López-Ruíz ${ }^{3}$, Sarah Parks ${ }^{2}$

Indicate who the corresponding author is by adding an asterisk next to the name of that author. If applicable, de manera concisa y precisa el contenido de tu trabajo. Los índices y motores de búsqueda utilizan las palabras en el título cuando están buscando información, así que te aconsejamos seleccionar tus palabras sabiamente.

Debes incluir la versión en inglés y en español del título de tu trabajo. El título, que debe colocarse al inicio de la página, no debe estar subrayado y no debe incluir citaciones ni coordenadas geográficas. Si incluyes el nombre de una especie, no incluyas la atribución; sin embargo, sí puedes presentar entre paréntesis la clase, el orden, la familia, etc., como corresponde.

Utiliza las mayúsculas como en una oración: utiliza mayúscula inicial sólo en la primer palabra del título y, si aplica, en los nombres propios.

- Nombre(s) de autor(es)

Deletrea tu nombre completo tal cual lo utilizas en todas tus publicaciones. Menciona primero el nombre(s) y luego el apellido(s). Coloca un asterisco al final del nombre completo del autor para la correspondencia.

Para los nombres completos de autores con más de un apellido, utiliza un guion entre los apellidos. No utilices un punto para abreviar un segundo nombre. Separa los nombres de los autores con una coma y no utilices la palabra "y" antes del último autor. Coloca números con formato superíndice de lado de los nombres de los autores para indicar la afiliación correspondiente; los números deben aparecer en orden numérica ascendente de izquierda a derecha a la primer mención. Considera los siguientes ejemplos:

\section{Sí}

James R Smith ${ }^{1}$, María López-Ruíz ${ }^{2}$, Sarah Parks ${ }^{3}$ James R Smith ${ }^{1}$, María López-Ruíz ${ }^{1}$, Sarah Parks ${ }^{2}$ James R Smith ${ }^{1}$, María López-Ruíz ${ }^{1,2}$, Sarah Parks ${ }^{3}$ James R Smith ${ }^{1}$, María López-Ruíz ${ }^{2,3}$, Sarah Parks ${ }^{2}$

\section{NO}

James R. Smith², María López-Ruíz ${ }^{1}$ y Sarah Parks ${ }^{3}$ James R. Smith ${ }^{1}$, María López-Ruíz ${ }^{3}$, Sarah Parks ${ }^{2}$

Indica quién es el autor para correspondencia con un asterisco en el nombre de ese autor. Si aplica, el asterisco (no en formato superíndice) debe colocarse de lado del superíndice numérico. Ejemplos:

\section{Carmen Sánchez*, Manuel Acosta}

James Smith ${ }^{*}$, María López-Ruíz ${ }^{2}$

Nota: el número tiene formato superíndice pero el asterisco no.

\section{- Afiliación del autor}

La afiliación del autor es la institución (las instituciones) de donde condujo la mayor parte del trabajo. 
the asterisk (not in superscript font) should follow the superscript number. Examples:

\section{Carmen Sánchez*, Manuel Acosta}

James Smith1*, María López-Ruíz ${ }^{2}$

Note: the number is a superscript but the asterisk is not.

\section{- Author affiliation}

The author's affiliation is the institution(s) where the primary research was conducted. Include the affiliation of every author and the corresponding mailing address. Complete affiliation information includes the following: department name, institution name, street address, city or town, state or other regional unit, postal code, and country (full names). Include the corresponding ORCID identifier for every author here.

List affiliations in ascending numerical order using the corresponding superscript number (as designated next to the author names) before each affiliation. Do not use superscript numbers when the affiliation is the same for all authors.

CM publishes authors from around the world, so it's highly advisable to consider the following precautionary measures when providing affiliation information:

- Affiliation located in more than one country: include only the postal address where you are located.

- Abbreviated forms of institution names: discouraged since the abbreviated form may vary in meaning or may not be recognized as metadata or by search engines. The full name of the institution is preferred.

- Translation of affiliation name: discouraged unless the institution officially acknowledges a translation of its name (e.g., University of Olso and Universitetet $i$ Olso are both displayed on the university's official website); in such cases, the English version should be used. The unofficial English translation of institution names not using Latin may be provided between brackets following the official name of the institution.

- Corresponding author

All correspondence will be dealt with the designated corresponding author. Provide the contact information (including e-mail) for this person.

- Running title

The running title is even shorter than the title and must not be more than 10 words long.

\section{- Abstract and key words}

The abstract briefly describes your entire work. Readers may determine from here whether they will read your
Incluye la afiliación de cada autor y la dirección correspondiente. La información completa de una afiliación debe incluir lo siguiente: nombre del departamento, nombre de la institución, nombre de la calle, ciudad, estado o unidad regional, código postal y país (no abreviado).

Menciona las afiliaciones en una lista numerada de manera ascendente y de acuerdo con los superíndices numéricos correspondientes señalados en cada autor. Los números de la lista de afiliaciones también deben presentarse en formato superíndice. No es necesario que utilices números superíndices si la afiliación es la misma para todos los autores.

CM publica trabajos de autores de diferentes partes del mundo, así que te aconsejamos considerar las siguientes medidas preventivas cuando proveas información de alguna afiliación:

- Afiliación localizada en más de un país: incluye sólo la dirección postal donde realizaste el trabajo y donde estás ubicado físicamente.

- Abreviaturas para los nombres de las instituciones: no aconsejadas porque la forma abreviada puede variar en significado y puede no ser reconocida por los metadatos o los motores de búsqueda. Es preferible utilizar el nombre completo de la institución.

- Traducción del nombre de la afiliación: desaconsejable salvo que la institución reconozca oficialmente una versión traducida de su nombre (e.g., los nombres University of Oslo y Universitetet $i$ Olso son ambos desplegados en la página web oficial de la universidad); en tales casos, debe utilizarse la versión en inglés del nombre. La versión de la traducción en ingles no oficial de los nombres de instituciones que no estén en latín puede presentarse entre corchetes después del nombre oficial de la institución.

- Autor para la correspondencia

Toda correspondencia se llevará a cabo con la persona designada como autor para la correspondencia. Provee la información de contacto (principalmente el correo electrónico) de esta persona.

- Título corto

El título corto debe ser aún más breve que el título principal y no debe exceder de 10 palabras.

- Resumen y palabras clave

El resumen brevemente describe todo tu trabajo. Es aquí donde los lectores pueden determinar si continúan leyendo tu artículo o buscan otro. Un resumen típico incluye una oración introductoria, una explicación general del método más importante, los hallazgos generales y una oración concluyente. La información en el resumen y las palabras clave también pasa la voz sobre tu trabajo, así que te aconsejamos seleccionar tus palabras sabiamente para esta sección. 
paper or move on to another one. Typical abstracts include an introductory sentence, a general explanation of most prominent methods, the overall findings, and a concluding sentence. The information here also gets the word out about your work, so be sure to choose your words wisely.

The maximum number of words is 300 for the abstract and 5 for keywords. Both the abstract and key words should be submitted in English and Spanish.

\section{- Body text}

The main body of the text should include the sections below in the order that they are listed. We do not accept a separate entry for conclusions. We also do not accept fusing results and discussion into a single section. Make sure you include all the material you have cited (e.g., references, tables, figures).

Sections of a manuscript

\section{- Introduction}

Keep the introduction short. Briefly mention what has been done, what your study is about, why you performed your study (e.g., objectives, hypothesis), etc.

- Materials and Methods

Be precise but concise. Mention what you used to perform your study and how you did it.

- Results

Mention only your results in this section. Do not discuss your results here. In running text, avoid describing information that has already been expressed in display elements (figures, tables).

- Discussion

Discuss your results: applications, implications, relevance, and/or comparison with other studies.

You can include a general conclusion of your work in a paragraph at the end of this section, but not in separate entry for conclusions.

- Acknowledgments

This section is meant to credit all those who funded the research or who made some contribution to the paper but did not meet the standards for authorship (e.g., proofreading, statistics, field work assistance, etc.).

Mention all funding sources first, permission notices next, and finally all other credits. The funding source is usually followed by the grant number in parenthesis, and the full name of the project need not be mentioned.

\section{- References}

References acknowledge the published works of others. Reviewers or readers may gather an idea of the baselines of your research from your list of references. Those interested in finding a work from your list will need accurate information. Be sure to include the references to all
El número máximo de palabras es de 300 para el resumen y de 5 para las palabras clave. Tanto el resumen como las palabras clave deben someterse en inglés y en español.

\section{- Cuerpo del texto}

El texto principal debe incluir las secciones que abajo se mencionan y en el orden en que se mencionan. No aceptamos una sección principal para las conclusiones. Tampoco aceptamos la fusión de resultados y discusiones en una sola sección. Asegúrate de incluir todo el material que citaste (e.g., referencias, tablas, figuras).

Secciones de un manuscrito

\section{- Introducción}

Mantén la introducción corta. Menciona de forma breve qué es lo que se ha hecho anteriormente, sobre qué trata tu estudio, porqué hiciste tu estudio (e.g., objetivos, hipótesis), etc.

- Materiales y métodos

Sé preciso pero conciso. Menciona qué utilizaste para realizar tu estudio y cómo lo hiciste.

- Resultados

Menciona solo tus resultados en esta sección. No discutas tus resultados aquí. En el texto corrido, evita describir información que ya se expresa bien en los elementos de apoyo (figuras, tablas).

- Discusión

Discute tus resultados: su aplicación, implicación, relevancia y comparación con otros estudios.

Puedes incluir una conclusión general de tu trabajo en un párrafo al final de esta sección, pero no en una sección principal de conclusiones.

- Agradecimientos

Esta sección tiene el propósito de dar crédito a todos aquellos que financiaron la investigación o que hicieron alguna contribución importante al artículo pero no lo suficiente para cumplir con los requisitos de autor (e.g., lectura de revisión, apoyo estadístico, apoyo en trabajo de campo, etc.).

Menciona primero las fuentes de financiamiento, luego los permisos y finalmente todos los demás créditos. La fuente de financiamiento regularmente va seguida del número del proyecto entre paréntesis, y no es necesario mencionar el nombre completo del proyecto.

\section{- Referencias}

Las referencias reconocen las publicaciones de otros. Con tu lista de referencias, los revisores y los lectores se pueden dar una idea de las bases de tu investigación. Aquellos que estén interesados en encontrar un trabajo mencionado en tu lista de referencias necesitarán información precisa. Asegúrate de incluir las referencias de todas las citas que mencionaste en tu manuscrito y de incluir las citas de todas las referencias en tu sección de referencias. El material que no es citado adecuadamente 
your citations and to cite all the references you listed in your manuscript. Incorrectly referenced material may be taken for plagiarism. The accuracy of references is the responsibility of the author. Unpublished material should not be used in references.

\section{How to reference}

For general cases use English. List your references in alphabetical order. For references with more than 10 authors, mention the first 10 author names and replace the remaining names by "et al." Separate author names by a comma. Mention the surname first and then the initial(s) of the given name(s) with no period. Where possible, please include, within square brackets, the English translation of non-English titles immediately after the original title. If a publication includes the English translation of its title (e.g., papers published in $\mathrm{CM}$ ), include both tiles separated by an equal sign. In the case of references with authors who use two surnames, include both surnames separated by a hyphen to distinguish them from the first name. If a reference has a Digital Object Identifier (DOI), then the DOI must be included in the reference and it should be displayed as a URL: (YES) https://doi.org/10.7773/cm.v44i4.2861; (NO) 10.7773/cm.v44i4.2861.

We generally use the Harvard style, with slight modifications. For a general idea on our style for references, please refer to the CSE manual of style and format and to the following examples:

\section{Journal paper:}

Teagle H, Hawkins SJ, Moore PJ, Smale DA. 2017. The role of kelp species as biogenic habitat formers in coastal marine ecosystems. J. Exp. Mar. Biol. Ecol. 492: 81-98. https://doi.org/10.1016/j.jembe.2017.01.017

\section{Book:}

MacGinitie GE, MacGinitie N. 1968. Natural History of Marine Animals. New York: McGraw-Hill. 523 pp.

\section{Book chapter:}

Rice ME. 1980. Sipuncula and Echiura. In: Morris RH, Abbott DP, Haderlie EC (eds.), Intertidal Invertebrates of California. Stanford, California: Stanford Univ. Press. P. 490-498.

\section{Published material with translation of title:}

Sánchez Marín P, Besada V, Beiras R. 2018. Use of whole mussels and mussel gills in metal pollution biomonitoring $=$ Uso del mejillón entero y de sus branquias en el biomonitoreo de la contaminación por metales. Cienc. Mar. 44(4): 279-294. https://doi.org/10.7773/ cm.v44i4.2861 puede interpretarse como plagio. La veracidad de las referencias es responsabilidad del autor. Las referencias no deben incluir material no publicado.

\section{Cómo componer una referencia}

Para casos generales utiliza el idioma inglés. Ordena tu lista de referencias en orden alfabético. Para referencias con más de 10 autores, menciona el nombre de los primeros 10 autores y reemplaza los demás nombres por "et al.". Separa los nombres de autores con una coma. Menciona primero el apellido y luego la inicial del primer nombre $\mathrm{y} / \mathrm{o}$ del segundo nombre sin punto. Siempre que sea posible, por favor incluye, entre corchetes e inmediatamente después del título original, la traducción al inglés no oficial de los títulos publicados en otro idioma que no sea el inglés. Si el trabajo publicado ya contiene la versión traducida en inglés (e.g., los artículos publicados en $\mathrm{CM}$ ), incluye ambos títulos y sepáralos con un signo de igualdad. En caso de que la referencia contenga nombres de autores que utilicen dos apellidos, separa los apellidos con un guion para distinguirlos del primer nombre. Si una referencia contiene un identificador digital de objeto (DOI, por sus siglas en inglés), incluye el URL del DOI en la referencia: (SÍ) https://doi.org/10.7773/cm.v44i4.2861; (NO) 10.7773/ cm.v44i4.2861.

En general, utilizamos el estilo Harvard con ligeras modificaciones. Para darte un idea general sobre nuestro estilo para las referencias, por favor, consulta el manual de estilo y formato del CSE y los siguientes ejemplos:

\section{Artículo de revista:}

Teagle H, Hawkins SJ, Moore PJ, Smale DA. 2017. The role of kelp species as biogenic habitat formers in coastal marine ecosystems. J. Exp. Mar. Biol. Ecol. 492: 81-98. https://doi.org/10.1016/j.jembe.2017.01.017

\section{Libro:}

MacGinitie GE, MacGinitie N. 1968. Natural History of Marine Animals. New York: McGraw-Hill. 523 pp.

\section{Capítulo de libro:}

Rice ME. 1980. Sipuncula and Echiura. In: Morris RH, Abbott DP, Haderlie EC (eds.), Intertidal Invertebrates of California. Stanford (CA): Stanford Univ. Press. P. 490-498.

\section{Publicación que incluye traducción del título:}

Sánchez Marín P, Besada V, Beiras R. 2018. Use of whole mussels and mussel gills in metal pollution biomonitoring $=$ Uso del mejillón entero y de sus branquias en el biomonitoreo de la contaminación por metales. Cienc. Mar. 44(4): 279-294. https://doi.org/10.7773/ cm.v44i4.2861 
Published material with non-English title:

Okolodkov YB. 2010. Biogeografía Marina [Marine Biogeography]. Campeche (Mexico): Universidad Autónoma de Campeche. 217 pp.

Organization as author:

[AOAC] Association of Official Analytical Chemists. 1990. Official Methods of Analyses. 15th Ed. Helrich K (ed.). Arlington (VA): AOAC. 1033 pp.

\section{Conference proceedings:}

González-Vázquez JA, Hernández-Vivar E, Jacobo-Villa MA. 2018. Análisis de circulación en estuarios. In: Lecertúa E, Lopardo MC, Menéndez A, Spalletti P (eds.), XXVIII Congreso Latinoamericano de Hidráulica: Trabajos Completos; 2018 September 18-21, Buenos Aires, Argentina. Argentina. P. 2281-2293.

\section{Technical or status report:}

[IATTC] Inter-American Tropical Tuna Commission. 2016. Tunas, billfishes and other pelagic species in the Eastern Pacific Ocean in $2015=$ Los atunes, peces picudos y otros peces pelágicos en el océano Pacifico Oriental en 2015. La Jolla (CA): IATTC. Fishery Satus Report, no. 14.

\section{Legal matter:}

[DOF] Diario Oficial de la Federación. 2002 Mar 6. Norma Oficial Mexicana NOM-059-ECOL-2001, Protección ambiental-Especies nativas de México de flora y fauna silvestres-Categorías de riesgo y especificaciones para su inclusión, exclusión o cambioLista de especies en riesgo. Mexico City: Secretaría de Gobernación.

\section{How to cite}

You should cite every reference you list in your manuscript. In general, mention the surname(s) and the year of publication. Make sure the surnames and the year of publication match the corresponding reference. For references with more than two authors, mention only the first author's surname followed by "et al." and the year. You may use in-text citations and parenthetical citations, the latter being the preferred format. If you are using multiple citations at a given point, arrange the series of citations in chronological order from oldest to newest and separate each citation by a comma; use a semicolon if in your series you include references from the same author, which should be separated by a comma. Please refer to the following examples:

\section{In-text citation:}

The analysis follows the procedure described in Smith (2015)...
Publicación con título no en inglés:

Okolodkov YB. 2010. Biogeografía Marina [Marine Biogeography]. Campeche (Mexico): Universidad Autónoma de Campeche. 217 pp.

Organización como autor:

[AOAC] Association of Official Analytical Chemists. 1990. Official Methods of Analyses. 15th Ed. Helrich K (ed.). Arlington (VA): AOAC. 1033 pp.

\section{Actas de conferencias:}

González-Vázquez JA, Hernández-Vivar E, Jacobo-Villa MA. 2018. Análisis de circulación en estuarios. In: Lecertúa E, Lopardo MC, Menéndez A, Spalletti P (eds.), XXVIII Congreso Latinoamericano de Hidráulica: Trabajos Completos; 2018 September 18-21, Buenos Aires, Argentina. Argentina. P. 2281-2293.

\section{Reporte técnico:}

[IATTC] Inter-American Tropical Tuna Commission. 2016. Tunas, billfishes and other pelagic species in the Eastern Pacific Ocean in $2015=$ Los atunes, peces picudos y otros peces pelágicos en el océano Pacifico Oriental en 2015. La Jolla (CA): IATTC. Fishery Satus Report, no. 14.

\section{Materia legal:}

[DOF] Diario Oficial de la Federación. 2002 Mar 6. Norma Oficial Mexicana NOM-059-ECOL-2001, Protección ambiental-Especies nativas de México de flora y fauna silvestres-Categorías de riesgo y especificaciones para su inclusión, exclusión o cambioLista de especies en riesgo. Mexico City: Secretaría de Gobernación.

\section{Cómo citar}

Debes citar toda fuente que incluyas en la lista de referencias de tu manuscrito. En general, menciona el(los) apellido(s) y el año de publicación. Asegúrate de que los apellidos y el año coincidan con los datos de la referencia que corresponde. Para las referencias con más de dos autores, menciona el apellido del primero autor, seguido de "et al." y el año. Puedes utilizar citaciones en el texto corrido o citaciones parentéticas, aunque la forma parentética es preferida. Si utilizas múltiples citaciones en un punto, acomódalas en orden cronológico de más antigua a más reciente y separa cada citación con una coma; separa las citaciones con punto y coma cuanto tu serie incluye referencias del mismo autor, las cuales deben separarse con una coma. Por favor consulta los siguientes ejemplos:

\section{In-text citation:}

El análisis se hizo de acuerdo con lo descrito en Smith (2015)... 
The procedure described in Smith et al. (2017)...

\section{Parenthetical citations:}

(Smith 2008)

(Smith 2008a, b)

(Morales and Pérez 2010)

(Morales et al. 2010)

(Morales et al. 2009, Willis 2010, Reynolds 2015)

(Morales 2008; Morales et al. 2009a, 2010; Reynolds 2015)

\section{- Tables and Figures}

The purpose of using display elements (figures and tables) is to clearly convey information without the use of lengthy explanations. Display elements should be self-explanatory. The reader must be able to interpret their contents without having to refer to the main text.

Figures or tables may be declined for publication anytime during the editorial process if failure to conform to journal standards. A total of 8 display elements are allowed. Number your display elements with Arabic numerals. When citing figures or tables, preferably in parenthetical form, capitalize the first letter (e.g., "Figure 1", "Fig. 1", or "Table 1"). Use the abbreviated form for figure citations in parenthetical form (e.g. "Fig. 1"). Cite figures and tables in ascending numerical order upon first mention; that is, do not cite Figure 2 if you have not yet cited Figure 1.

Insert figure captions, tables, and figures after the references in the following order:

\section{- Figure captions}

Figure captions should concisely describe the figures. If your manuscript contains figures, list the corresponding captions in the correct consecutive order on a separate page after the references. If your manuscript is accepted for publication and you will be the one providing the corresponding translation, you will be asked to send the translation for the figure captions.

The figure and the caption together say the whole story without any reference to the text. You should then treat abbreviations in the caption as if they were mentioned for the first time. All abbreviations or symbols used in a figure should be described in a key legend or in the caption, even if they were already defined in the text. When the figure caption is similar to another, type in the entire caption instead of typing "Same as Figure X." For example:

\section{YES}

Figure 1. Seasonal climatology for temperature.

Figure 2. Seasonal climatology for salinity.

Figure 3. Seasonal climatology for chlorophyll.
El procedimiento descrito en Smith et al. (2017)...

\section{Parenthetical citations:}

(Smith 2008)

(Smith 2008a, b)

(Morales and Pérez 2010)

(Morales et al. 2010)

(Morales et al. 2009, Willis 2010, Reynolds 2015)

(Morales 2008; Morales et al. 2009a, 2010; Reynolds 2015)

\section{- Tablas y figuras}

El propósito de utilizar elementos de apoyo (figuras y tablas) es comunicar información de manera clara sin necesidad de dar explicaciones largas. Los elementos de apoyo deben explicarse por sí solos. El lector debe poder interpretar el contenido de estos sin tener que referirse al texto principal.

La publicación de figuras y tablas puede ser declinada en cualquier momento del proceso editorial si estos elementos no se apegan a los estándares de la revista. Admitimos el uso de hasta 8 elementos de apoyo. Numera tus elementos de apoyo consecutivamente con números arábigos. Cuando cites tus figuras o tablas, preferentemente de forma parentética, escribe la primer letra con mayúscula (e.g., "Figura 1", "Fig. 1" o "Tabla 1"). Utiliza la forma abreviada para la citación parentética de las figuras (e.g. "Fig. 1"). Cita las figuras y las tablas en orden numérico ascendente cuando las menciones por primera vez; es decir, no cites la Figura 2 si aún no has citado la Figura 1.

Inserta los pies de figura, las tablas y las figuras después de las referencias en el siguiente orden:

- Pies de figura

Los pies de figura deben describir las figuras de manera concisa. Si tu manuscrito contiene figuras, presenta tu lista de pies de figura en el orden consecutivo correcto en una hoja aparte después de las referencias. Si tu manuscrito fue aceptado y tú proveerás la traducción correspondiente, asegúrate de incluir la traducción de los pies de figura.

La figura y el pie de figura, juntos, lo explican todo sin alguna referencia al texto. Entonces, deber tratar las abreviaturas en los pies de figura como si las mencionaras por primera vez. Toda abreviatura o símbolo usado dentro de la figura debe estar descrito ya sea en una clave dentro de la figura o en el pie de figura, aún si ya lo definiste en el texto principal. Cuando el pie de figura sea similar a otro, escribe la descripción completa en lugar de escribir "Lo mismo que en la Figura X”. Por ejemplo:

\section{SÍ}

Figura 1. Climatología temporal para la temperatura. Figura 2. Climatología temporal para la salinidad. 


\section{NO}

Figure 1. Seasonal climatology for temperature.

Figure 2. Same as Figure 1 for salinity.

Figure 3. Same as Figure 1 for chlorophyll.

\section{- Tables}

Tables should be self-explanatory, independent of the main text. Present each table with a concise title. You may define abbreviations in the title. Table titles are published in English and Spanish. If your manuscript is accepted for publication and you will be the one providing the corresponding translation, you will be asked to send the translation for the table titles.

Please

- Use only English for text inside the tables

- List tables after the page containing the list of figure captions

- Number tables consecutively using Arabic numerals, and cite them as such in the main text upon first mention (do not cite Table 2 if you have not cited Table 1).

- Make sure you cited all the tables you presented and that you send all the tables you have cited.

\section{- Figures}

Figures include maps, graphs, charts, photographs, and other artwork. Together the figure and the corresponding caption should be self-explanatory, allowing proper interpretation standing alone. Every element (line, circle, color, number, text, and other objects) included in a figure should serve a purpose and its meaning should be well understood without any reference to the main text. Avoid unnecessary elements such as decorative matter and gridlines. Include the appropriate labels and place units in parentheses. Treat labels and abbreviations in every figure as if they were mentioned for the first time; define them in the caption or in a key legend.

Please

- Use only English for descriptive text within the figure.

- Include figures after the tables.

- Number figures consecutively using Arabic numerals and cite them as such upon first mention (do not cite Figure 2 if you have not cited Figure 1)

- Make sure you cited all the figures you presented and that you send all the figures you have cited.

Color figures are discouraged unless absolutely necessary. The editor-in-chief will ultimately determine if a color figure is accepted for publication. Caution is advised for use of colors. When using colors to contrast different results, please, take into consideration.
Figura 3. Climatología temporal para la clorofila.

NO

Figura 1. Climatología temporal para la temperatura.

Figura 2. Lo mismo que en la Figura 1 pero para la salinidad.

Figura 3. Lo mismo que en la Figura 1 pero para la clorofila.

- Tablas

Las tablas deben explicarse por sí solas e independientemente del texto principal. Presenta cada tabla con un título conciso. Puedes definir las abreviaturas en el título. Los títulos de las tablas son publicados en inglés y en español. Si tu manuscrito fue aceptado para publicación y tú serás el que proveerá la traducción correspondiente, asegúrate de incluir la traducción de los títulos de la tablas.

Por favor

- Utiliza sólo el inglés para el texto dentro de las tablas

- Coloca las tablas después de la página que contiene la lista de pies de figura

- Numera las tablas de manera consecutiva con número Arábigos, y cítalas de esa manera cuando las menciones por primera vez (no cites la Tabla $2 \mathrm{si}$ aún no has citado la Tabla 1)

- Asegúrate de haber citado todas las tablas que presentaste y de enviar todas las tablas que citaste en el texto

\section{- Figuras}

Las figuras incluyen mapas, gráficas, ilustración cartográfica, fotografías y otros trabajos de arte. La figura y el pie de figura correspondiente, juntos, deben explicarse por sí solos y permitir que el lector entienda la figura sin ver el texto principal. Cada elemento (línea, círculo, color, número, texto y otros objetos) incluido en la figura debe servir un propósito y su significado debe entenderse sin tener que hacer referencia al texto. Evita utilizar elementos innecesarios como elementos decorativos o líneas de rejilla. Incluye las etiquetas apropiadas y coloca las unidades entre paréntesis. Maneja las etiquetas y las abreviaturas en cada figura como si las estuvieras mencionando por primera vez; defínelas en el pie de figura o en claves dentro de la figura.

Por favor

- Utiliza sólo el inglés para el texto descriptivo dentro de la figura

- Coloca las figuras después de las tablas

- Numera las figuras de manera consecutiva con número Arábigos, y cítalas de esa manera cuando 
Free color-impairment simulators like ColorOracle will allow you to test if the colors you are using can be distinguished by people with color vision impairment. If your manuscript is accepted and it includes color figures, our in-house editors may suggest using different colors when, after examining your figure, they determine that the original colors cannot be easily contrasted by everyone.

You are responsible for obtaining all permissions required for publishing the figures in your manuscript, especially if you do not hold the rights to them.

If your manuscript is accepted for publication, you will be asked to send the digital editable format of your figures. Please see the Manuscript preparation for final submission guidelines for more specific details on this.

\section{- Supplementary material}

Supplemental content is occasionally accepted for publication. If applicable, place supplementary material after the figures, and label as Figure S1 or Table S1 as appropriate. Like the main tables and figures, this material should be listed in ascending numerical order, tables first. Citation in running text should also follow this order upon first mention.

\section{Manuscript preparation for final submission}

If your manuscript is accepted for publication, please send the final accepted version and the corresponding translation in separate Misrosoft Word files. Do not send both versions in a single file. You must include the translation of table titles, figure captions, and, if applicable, titles and captions of supplementary material. Please note that even if you request that translation be done by our in-house translator, you still need to provide the translated version of the main title, abstract, and key words.

Also, send you figures files separately. Name your figure files using your manuscript number and the appropriate figure number. Figure files must be sent in digital editable format. By editable, we mean that all figure elements (objects, lines, legends, letters, numbers, etc.) should be independent to be modified separately as required. To obtain editable files, we suggest saving or exporting figure files from the source program in the following formats:

Windows Metafile (.wmf), Corel Draw (.cdr), Adobe Illustrator (.ai), Portable Document Format (.pdf), Scalable Vector Graphics (.svg), Microsoft Excel Worksheet (.xlm), and Encapsulated PostScript (.eps).

For photographs, we accept the following formats:

Joint Photographic Experts Group (.jpeg), Tagged Image File Format (.tiff), o Portable Network Graphics (.png). las menciones por primera vez (no cites la Figura 2 si aún no has citado la Figura 1)

- Asegúrate de haber citado todas las figuras que presentaste y de enviar todas las figuras que citaste en el texto

No aconsejamos utilizar figuras a color salvo que sea absolutamente necesario. El editor-en-jefe será el que finalmente determinará si la figura a color es aceptada para la publicación. Aconsejamos tomar precauciones en el uso de colores. Cuando utilices color para contrastar diferentes resultados, por favor, considera que algunos lectores pueden tener capacidades visuales diferentes. Existen simuladores de color gratis (e.g., ColorOracle) que te permiten probar si los colores que estás utilizando pueden ser contrastados por personas con capacidades visuales diferentes. Si tu manuscrito es aceptado y contiene figuras a color, los editores internos te podrán aconsejar el uso de algunos colores cuando, después de examinar la figura, determinen que los colores originales no pueden ser fácilmente contrastados por todos.

Tú tienes la responsabilidad de adquirir los permisos necesarios para publicar las figuras de tu manuscrito, especialmente si tú no posees los derechos de autor de estas.

Si tu manuscrito es aceptado para publicarse, te solicitaremos enviar tus figuras digitales en formato editable. Por favor lee las directrices Preparación del manuscrito para el envío final para ver los detalles específicos al respecto.

\section{- Material suplementario}

Ocasionalmente, aceptamos la publicación de contenido suplementario. Si aplica en tu caso, coloca el material suplementario después de las figuras y etiquétalo como Figura S1 o Tabla S1, según sea el caso. Así como para las figuras y tablas principales, este material debe etiquetarse en orden numérico ascendente, tablas primero. La citación de este material en el texto corrido debe seguir este mismo orden a la primer mención.

\section{Preparación del manuscrito para el envió final}

Si tu manuscrito es aceptado para ser publicado, por favor envía la versión final aceptada y la traducción correspondiente en archivos Misrosoft Word separados. No envíes amabas versiones en un solo archivo. Debes incluir la traducción de los títulos de las tablas, los pies de figura y, si aplica, los títulos del material suplementario. Por favor, nota que aunque hayas solicitado que la traducción la realice el traductor de CM, de todas formas debes enviar la traducción del título principal, el resumen y las palabras clave. 
In addition, use a resolution higher than 300 dpi. Do not include any legends or symbols (e.g., scale-bars, arrows or letters, and numbers) in the photograph file you send separately. We will use the original image in your manuscript as reference.

\section{BibLIOGRAPHY}

Ahmed HS, Gasparyan AY. 2013. Criticism of peer review and ways to improve it. European Science Editing 39(1): 8-10.

Albert T, Wager E. 2003. How to handle authorship disputes: a guide for new researchers. [accessed 2018 Feb]. England: Committee on Publication Ethics. https://publicationethics.org/files/2003pdf12_0.pdf

BioMed Central. [2019] . Text recycling guidelines. [accessed 2019 Mar]. England: Committee on Publication Ethics. https:// publicationethics.org/files/Web_A29298_COPE_Text_ Recycling.pdf

Committee on Publication Ethics. 2011. Code of Conduct and best practice guidelines for journal editors. [accessed 2019 Mar]. England: Committee on Publication Ethics. https:// publicationethics.org/files/Code\%20of\%20Conduct.pdf.

Committee on Publication Ethics. 2017. COPE ethical Guidelines for Peer Reviewers. [accessed 2018 Feb]. England: Committee on Publication Ethics. https://publicationethics.org/files/ Ethical_Guidelines_For_Peer_Reviewers_2.pdf

Committee on Publication Ethics. 2019. Cooperation between research institutions and journals on research integrity cases: guidance COPE. England: Committee on Publication Ethics. https://doi.org/10.24318/cope.2018.1.3

Committee on Publication Ethics. 2019. Guidelines for retracting articles. England: Committee on Publication Ethics. https://doi.org/10.24318/cope.2019.1.4

Committee on Publication Ethics. 2019. Text recycling guidelines for editors. England: Committee on Publication Ethics. [accessed 2019 Mar]. https://publicationethics.org/textrecycling-guidelines.

Council of Science Editors. 2012. CSE's White Paper on Promoting Integrity in Scientific Journal Publications, 2012 Update. Wheat Ridge (CO): Council of Science Editors. $81 \mathrm{pp}$.

Council of Science Editors. 2014. Scientific Style and Format: The CSE Manual for Authors, Editors, and Publishers. 8th Ed. Chicago (USA): The University of Chicago Press. $722 \mathrm{pp}$.

Fundación Española para la Ciencia y la Tecnología. 2012. Manual de buenas prácticas en edición de revistas científicas. Spain: Editorial MIC. 86 pp.

Graf C, Wager E, Bowman A, Fiack S, Scott-Lichter D, Robinson A. 2007. Best practice guidelines on publication edthics: a publisher's perspective. Int. J. Clin. Pract. 61 (Suppl. 152): 1-26. https://doi.org/10.1111/j.1742-1241.2006.01230.x.

Gollogly L, Momen H. 2006. Ethical dilemmas in Scientific publication: pitfalls and solutions for editors. Rev Saúde Pública 40(N Esp): 24-29.

Jenny B, Vaughn-Kelso N. 2007. Color Design for the Color Vision Impaired. Carthographic pespectives 58: 61-67.

International Council for Laboratory Animal Science. 2015. Ethics and Animal Welfare Committee. [accessed 2019 Mar]. International Council for Laboratory Animal Science. http://iclas.org/committees/ethics-and-animal-welfarecommittee.
También envía los archivos de tus figuras por separado. Etiqueta tus archivos utilizando el número de tu manuscrito y el número correspondiente de la figura. Los archivos de las figuras deber ser enviados en formato digital editable. Por editable, queremos decir que todos los elementos de la figura (objetos, líneas, leyendas, letras, números, etc.) deben poder editarse de manera independiente, según sea el caso. Para obtener archivos editables, sugerimos guardar o exportar los archivos de figuras desde el programa original en los siguientes formatos:

Windows Metafile (.wmf), Corel Draw (.cdr), Adobe Illustrator (.ai), Portable Document Format (.pdf), Scalable Vector Graphics (.svg), Microsoft Excel Worksheet (.xlm) y Encapsulated PostScript (.eps).

Para las fotorgafías, aceptamos los siguientes formatos:

Joint Photographic Experts Group (.jpeg), Tagged Image File Format (.tiff) o Portable Network Graphics (.png).

Además, requerimos que las fotografías tengan una resolución de 300 dpi. No incluyas leyendas o símbolos (e.g., barras de escala, flechas, letras o números) en los archivos de fotografía que envíes por separado. Utilizaremos la imagen original en tu manuscrito como referencia.

Traducido al español por Melba De Jesus y Claudia Michel-Villalobos.

Kelly D, Jasperse J, Westbrooke I. 2005. Designing Science Graphs for Data Analysis and Presentation. Wellington (New Zealand): Science and Technical Publishing Department of Conservation. $68 \mathrm{pp}$.

Loos EM. 2000. Evaluating scientific illustrations: Basics for editors. Science Editor 23(4): 124-125.

Luk. 2015 Feb 7. Tips for designing scientific figures for color blind readers. [accessed 2019 Mar 15]. Somersault18:24. http://www. somersault1824.com/tips-for-designing-scientific-figures-forcolor-blind-readers/.

Mandal J, Ponnambath DK, Parija SC. 2016. Ethics in scientific publication. Trop. Parasitol. 6(2): 100-102.

National Centre for the Replacement, Refinement and Reduction of Animals in Research. 2019. The 3Rs. [accessed 2019 Mar 15]. London (United Kingdom): NC3Rs. https://www.nc3rs.org.uk/ the-3rs.

Osborne N, Avey MT, Anestidou L, Ritskes-Hoitinga M, Griffin G. 2018. Improving animal research reporting standards: HARRP, the first step of a unified approach by ICLAS to improve animal research reporting standards worldwide. EMBO reports 19: e46069. https://doi.org/10.15252/embr.201846069.

Real Academia Española. 2010. Nueva Gramática de la lengua española: Manual. Mexico City: Editorial Planeta Mexicana. 
Real Academia Española. 2011. Ortografía de la lengua española. Mexico City: Editorial Planeta Mexicana.

Real Academia Española. 2019. Diccionario de la Real Academia Española: Edición del Tricentenario. [accessed 2019 Mar] Madrid (Spain): Real Academia Española. https://dle.rae. es/?id=TmjwQbV.

Rossner M, Yamada KM. 2004. What's in a Picture? The temptation of image manipulation. J. Cell Biol. 166(1): 11-15. http://www.jcb.org/cgi/doi/10.1083/jcb.200406019.

Rubens P (ed.). 2001. Science and Technical Writing: A manual of Style. 2nd Ed. New York (NY): Routledge. 427 pp.

Russell WMS, Burch RL. 1992. The Principles of Humane Experimental Technique. [Special edition]. Baltimore (MD): Johns Hopkins University. [accessed 2019 Mar 15]. http:// altweb.jhsph.edu/pubs/books/humane_exp/het-toc.

Schofield EK. 2002. Quality of graphs in scientific journals: An Exploratory Study. Science Editor 25(2): 39-41.
Steen RG. 2013. Authorship: to be or not to be? European Science Editing 39(1): 6-8.

Turner PV, Pekow C, MacArthur-Clark J, Vergara P, Bayne K, White WJ, Kurosawa TM, Seung-Hyeok S, Baneux P. 2015. Roles of the International Council for Laboratory Animal Science (ICLAS) and International Association of Colleges of Laboratory Animal Medicine (IACLAM) in the Global Organization and Support of 3Rs Advances in Laboratory Animal Science. J. Am. Assoc. Lab. Anim. Sci. 54(2): 174-180.

University of Chicago. 2010. The Chicago Manual of Style: The Essential Guide for Writers, Editors, and Publishers. 16th Ed. Chicago (USA): The University of Chicago Press. 1027 pp.

Wager E. 2010. Why you should not submit your work to more than one journal at a time. Afr. J. Trad. CAM 7(2): 160-161.

Wiley (US). Best Practice Guidelines on Publishing Ethics: A Publisher's Perspective. 2nd Ed. [Location unknown]: John Wiley and Sons. $56 \mathrm{pp}$. 